\title{
FAUNA PRESERVATION IN N'GAMILAND
}

\section{By ROBERT AND JUNE KAY}

Schemes for the preservation of fauna in Kenya, Tanganyika, and Uganda are much to the fore at the present time, and quite rightly so, but we would like to advance the claims of N'gamiland as being one of the finest places of them all where the wild life of Africa may yet be found in its almost pristine state, rivalling that of N'gorongoza, the Serengeti Plains and the Ngorongoro Crater. We plead also the urgent need for the formation of a society dedicated to the protection of the fauna in support of an understaffed and overworked Game Department.

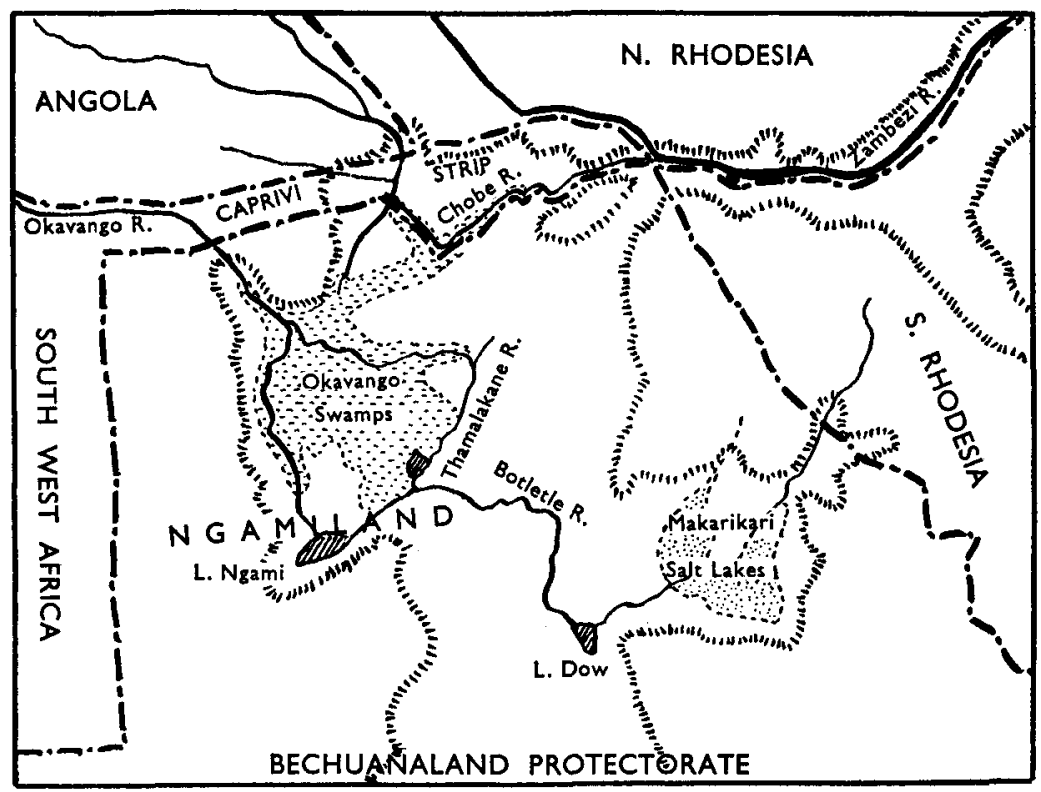

N'gamiland lies in the extreme north-western corner of the Bechuanaland Protectorate in south central Africa. Although the whole Protectorate is administered by the Colonial Office through the High Commissioned Territories, N'gamiland is a comparatively separate entity. The inhabitants comprise members of many different tribes, but the ruling tribe is the Batawana. The Okavango river, rising in the Angolan Highlandswhere the rainfall is usually upwards of 120 inches a year-flows southeast through the Caprivi Strip and enters N'gamiland on its northwestern border. This river never finds its way to the sea but flows into the great depression of south central Africa made up of the Okavango Swamps, Lakes N'gami and Dow and the Makarikari Salt Lakes. Before the onset of the present interpluvial period, and many hundreds of years 
ago, this depression was without doubt a great freshwater inland sea, the ancient shorelines of which are still traceable. It is also within the area which, according to Professor Raymond Dart and others, acted as the cradle of mankind, for the Australopithicinae were originally found at Taungs in British Bechuanaland. The Okavango Swamps in their turn drain into the Thamalakane river flowing into Lake N'gami and the Botletle river flowing towards Lake Dow, which, when full, overflows into the Makarikari Salt Lakes. The Swamps themselves are, in fact, an inland delta approximately 180 miles along the base and 300 miles from the base to the apex. The term "swamp" is a trifle misleading, for it is not akin to mangrove swamp but is an intricate maze of crystal-clear waterways and white sand. To a photographer's eye the country looks over-exposed in its bleached green, smudged yellows, and hazy indigo, but has an intensely compelling beauty of its own. The deep heart of the Swamp contains sedge, papyrus, water grass, and floating sud, the channels bordered by an undefined shore of unstable vegetable matter, the roots of the swamp grasses interlaced below the level of the water and sometimes going down to a depth of 10 feet or more. On this uneasy footing wind-driven soil has afforded a purchase for small semi-aquatic plants and short grass, apparently presenting a solid surface, that can break away treacherously under the feet. Along the edge of the Swamps and waterways there is found, for the most part, a narrow strip of grassland, grazed close as a lawn by countless thousands of antelope. Beyond this lies heavy riverine forest full of trailing lianas and black-faced vervet monkeys. The whole area is surrounded by thick belts of mopane, a hardwood tree with a butterflyshaped leaf of high nutritional value to herbivorous animals. This is semi-desert country, the soil being almost entirely Kalahari sand.

The extraordinary variety of ecological conditions in the Swamps and their surroundings make a suitable habitat for an immense variety of living creatures. At the centre there are marsh and water-loving animals : hippo, lechwe, sitatunga, and crocodile. Moving out of the swamp and along the border there are elephant, buffalo, zebra, blue wildebeest, water-buck, sable and roan antelope, tsessebe, greater kudu, impala, reed buck, wart hog, baboon, and vervet monkey. There are also lion, leopard, cheetah, caracal lynx, serval, civet, gennet, African wild cat, hunting dog, and spotted hyaena. The brown hyaena occurs on the fringes of the desert by the Botletle river. In the Swamp area there are also both black-backed and side-striped jackal, aardwolf, Delande's fox and giraffe.

Further into the dry country, we find the greater kudu, eland, the pretty Chobe bush buck and the gemsbuck.

In the riverine country there is a wonderful array of birds too numerous to consider in this article.

In three and a half years of intensive Swamp travel in an amphibious D.U.K.W., which is the main vehicle of our safari unit, we have come to the conclusion that, owing to the peculiar isolation of the area, various species have developed along lines of their own. Some of our giraffes look like the reticulated and we have a singularly attractive pinky-buff African wild cat, with the banding on the legs and tail barely discernible; the pelts of these animals are an almost uniform apricot colour. Paraxerus 


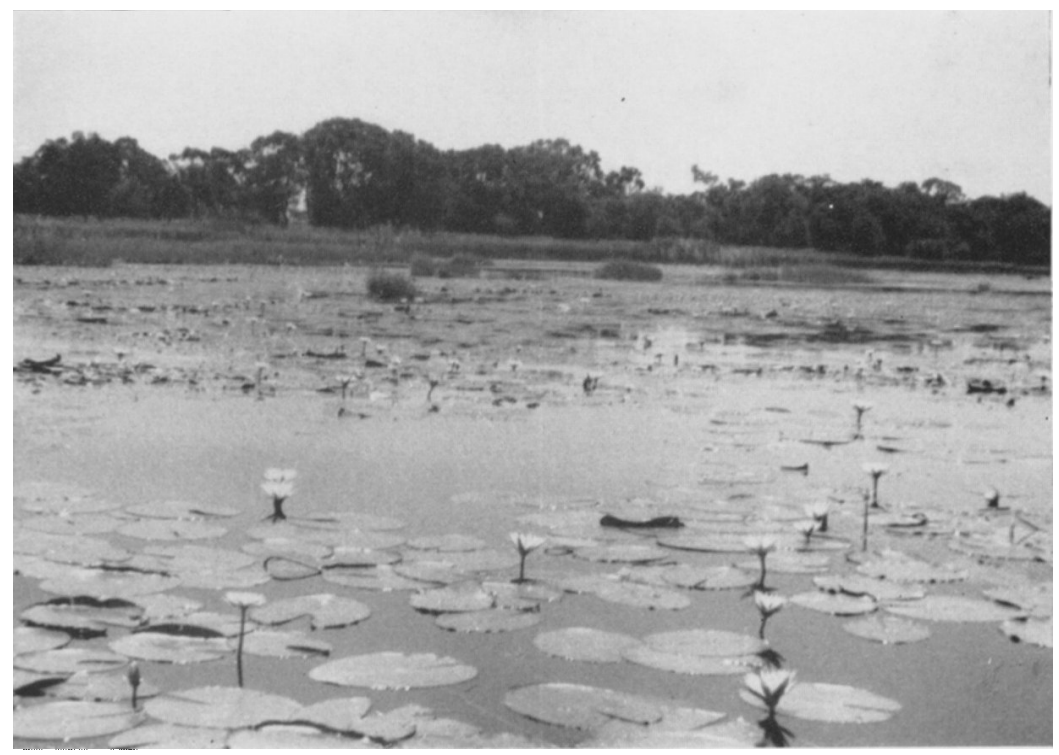

OKAVANGO SWAMPS, N'GAMILAND

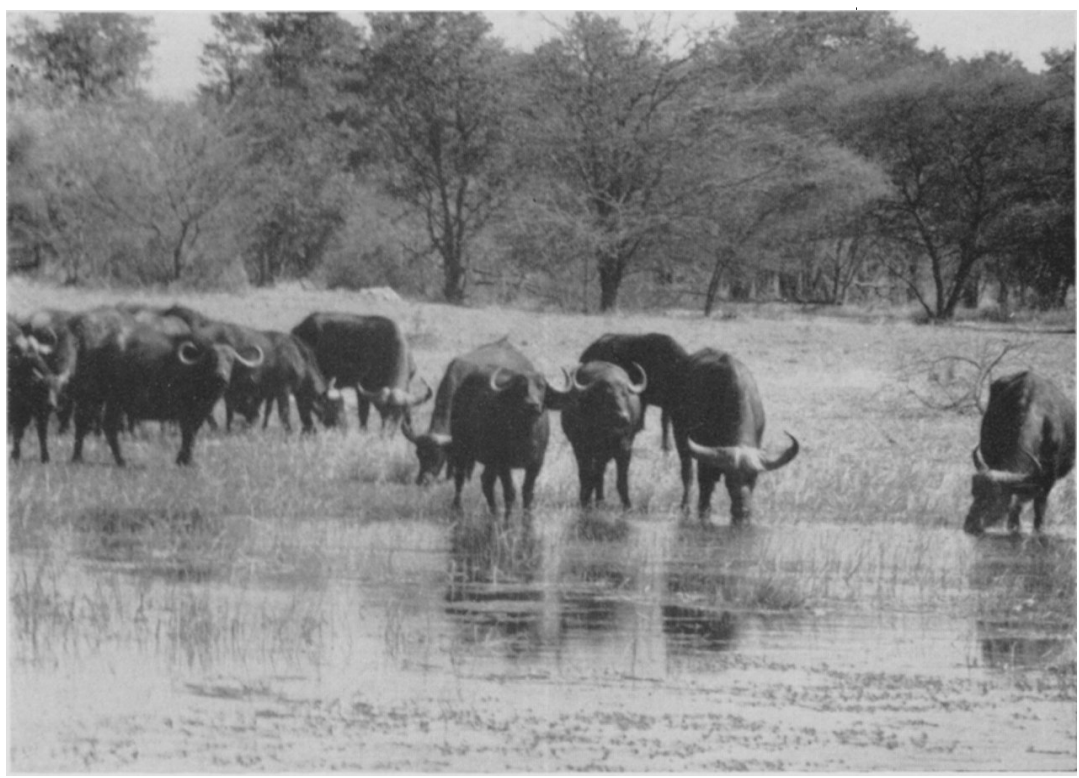

BUFFALO IN A MOLAPO, OKAVANGO SWAMPS

(A molapo is low-lying grassland that becomes flooded when the water-level is high.) 
cepapi maunensis, a sub-species of bush squirrel peculiar to N'gamiland and to the Thamalakane river in particular, is to be found in abundance. In a very remote area we once encountered a herd of five kudu cows carrying horns - of the animals' sex there could be no dispute, for we not only had a close-up view but we watched three of them suckling their calves. As far as we know kudu cows with horns have never previously been recorded. The horns were about half the size of those carried by an average kudu bull.

The area along the northern border of the Okavango Swamps and stretching to the Chobe or Linyanti river is still comparatively undisturbed by man. In consequence the fauna is so tame that we have approached to within six feet of buffalo and to within ten feet of a lone bull elephantadmittedly he was facing away from us. During the course of a short morning's walk it is possible to see an amazing variety of animals.

How is it, one may ask, that such an area could remain undisturbed to this very day? The answer is two-fold: firstly, the hundreds of square miles of semi-desert around the Swamps was in the past an almost insurmountable obstacle-indeed F. C. Selous has referred to the desert area as "the thirstland"; secondly, the abundance of tsetse fly, carrier of sleeping sickness in man and nagana in cattle has shielded the country against permanent settlement.

Human Inhabitants. - Within this huge region there are approximately only 50,000 human inhabitants, and these are for the most part concentrated in and around a few tribal villages and isolated settlements. The tribesmen are by no means robust, for malaria, tuberculosis, leprosy, and many other diseases have sapped their strength. They have little culture and few handicrafts but, where the tsetse fly allows, keep cattle and goats. Hunting rights are traditional and jealously guarded. By selling a proportion of the meat made into unsalted biltong and skins converted into karosses or fur blankets, the hunter's family obtains a little money.

The great tragedy for the animals is that almost any method is used to ensure their capture. Steel jaw traps are perhaps the most terrible, condemning the victim to hours of torture, often in the full blaze of the tropical sun, for traps are by no means regularly visited, and the captives, when found, may be bludgeoned to death to save the cost of a bullet. The old smooth-bore Martini Henry, totally inaccurate at over 10 yards range and the bulk of them museum specimens, are in general use. Bullets are cut out of carcasses and hammered back into shape time and again, and far more game is wounded than is killed. The import of high powered modern rifles for use by the Batawana is strictly controlled, but should they ever be allowed into the country in any quantity their superior killing power would soon decimate the game.

There is, thus, a serious dilemma to which the fundamental answer lies in persuading the indigenous population that they have in the fauna an invaluable heritage which can be turned into an asset of great economic benefit.

In East Africa the profits of safari firms have gone to the firms themselves. Although governments have received considerable revenue from the sale of game licences and money has been spent in the country as a 
result of safaris, there has been little immediate, direct or obvious benefit to the indigenous population. The African, when he has not been made aware of the value of the game to himself, is likely to slaughter indiscriminately if control is removed.

An especial danger to the fauna of N'gamiland has been the kind of European hunting party which comes complete with vehicles, supplies, and ammunition. Such parties, apart from the purchase of their licences and a modicum of alcohol and cigarettes, have been of very little benefit to the economy of the country - without considering the loss of its fauna, often in substantial quantities. Some of these parties have endeavoured to defray the cost of their safaris by taking back with them as many lion and leopard skins and as much biltong as they can lay their hands on. This attitude is the negation of that of the true sportsman, and has been further worsened by frequent use of steel traps. The Game Department of Bechuanaland fights a lone battle, inadequately staffed, under-financed, and circumscribed to some extent by the antipathy of vested cattle interests.

Bearing in mind that the lynch-pin of the problem of preserving intact the fauna of this unique area is the whole-hearted co-operation of the indigenous population, and that this can only be achieved by its being of direct financial benefit to them, the following proposals are put forward :

(1) To form a Bechuanaland Fauna Preservation Society, devoted to the preservation of the wild life of the country.

(2) To establish a controlled area in the Okavango Swamps, judicious cropping of game being carried out by authorized parties of hunters only. Great stress should be laid upon photographic safaris.

(3) To arrange that a percentage of the profits of all hunting safaris shall be remitted direct to the tribal treasury. Means must be found of distributing these profits so as to show direct benefit to the individuals of the resident tribe.

(4) To prevent undesirable hunting parties of the kind described above from entering Bechuanaland.

(5) The use of steel jaw traps in N'gamiland and, indeed, in the whole Protectorate should be gradually discouraged, until their use can be altogether forbidden.

The need is urgent. At the present time there is little or no racial friction in this corner of Africa and it is quite possible to establish a multiracial enterprise like this. Thus, when the time comes for the British administration to relinquish its guiding hand, there will be an established group of the indigenous population trained in the technique of fauna conservation and alive to its traditions.

\section{AN APpeal}

We most earnestly appeal to those interested in the preservation of African wild life to help us to establish a society for the preservation of the fauna of Bechuanaland. It must be done now lest future racial tensions should make impossible a multi-racial effort of this kind. 
We especially need local people to help directly by personal endeavour, but we ask for members outside Bechuanaland as well.

We also need visitors either on photographic safaris, or as members of controlled hunting parties.

Please write to :

ROBERT and JUNE KAY,

c/o The National and Grindlays Bank, Ltd.,

P.O. Box 1778,

BULAWAYO,

Southern Rhodesia,

Africa. 